\title{
Research on the Evolution of Chinese Local Government Special Bond Management System in the Perspective of Opportunistic Behavior
}

\author{
Zhang Chunyan ${ }^{1, a}$, Xie Ping ${ }^{2, b}$ \\ ${ }^{1}$ Ningbo University of Finance and Economics, NINGBO ZHEJIANG CHINA \\ ${ }^{2}$ Ningbo University of Finance and Economics, NINGBO ZHEJIANG CHINA \\ E-mail: fire2050@163.com, E-mail:xieping000624@126.com \\ *Zhang Chunyan
}

Keywords: Opportunism; Local government bond; Administration system on stock issuance

\begin{abstract}
The opportunistic behavior in the process of restricting local government borrowing is a matter that the central government needs to consider firstly when setting up the management system of local government bond issuance. The local government bond issuance system was spawned by financial crisis, and its distinctive administrative control model has constrained the in-depth development of the market, and then the subsequent system reforms by the central government drove its issuance scale expansion and products increase. However, under the condition of asymmetric information, it is still a problem that how to meet the financing needs of local government and prevent its excessive borrowing at the same time, which needs to be discussed in depth.
\end{abstract}

\section{Introduction}

Chinese local government bonds have experienced a leap-forward development since its issuance resumption in 2009, which issuance scale has gradually increased from the initial 200 billion yuan to a peak of 6 trillion yuan in 2016. Although the issuance in 2017 declined, its overall stock exceeded the national debt for the first time, reaching 14.74 trillion yuan. The rapid expansion of the Chinese local government bonds scale has sparked debate about whether the central government is relaxing the regulation of local bond issuance. This paper argues that China's local government bonds adopt the administrative control model with the approval system as the core. The central government has always controlled the local government bonds issuance by the approval system to prevent the opportunistic behavior of local governments.

\section{Opportunistic behavior in the process of local government bonds issuance}

Oliver Williamson, a economist of new institution, firstly explained the opportunistic behavior: The human nature is that they will not hesitate to harm others to benefit themself whenever they can, and always exert all their effort to protect and increase their own interests in economic activities; Opportunistic behavior leads to higher transaction costs, and the more complex the transaction, the greater the increase in transaction costs; Opportunistic behavior exists owing to the externality and asymmetric information.

The local government, theoretically, is the subject of the issuance of local government bonds. In the jurisdiction of local governments, residents and enterprises, as the micro economic agents, are the direct driving force for economic development. Under the premise that population and assets can flow freely, the cross-regional flow of micro economic agents becomes the main factor for restraining the economic behavior of local governments. In order to attract and retain high-quality talents and enterprises, local governments compete in providing high-level public services, reducing land prices, and more preferential policies. The implementation of these measures requires adequate financial support. Since that the tax is subject to various restrictions, the main way for the local government to obtain funds is to issue bonds. For the purpose of improving the satisfaction of micro economic agents, local governments generally have a tendency to expand debt. 
The second generation of fiscal decentralization theory further pointed out that due to the objective existence of information asymmetry, it is very difficult for the central government and local residents to supervise local officials. When supervision of local governments become a mere formality, the behavior of local government officials will be consistent with the Niscaran model, which maximizes the budget of officials and maximizes the utility of officials. Local officials have tried to expand public spending to create opportunities for rent and rent-seeking for the purpose of maximizing utility, which not only directly promoted the increase of local public expenditure but also spawned a large amount of local debt. Through the dual driving force of political achievements and rents, local government officials actively expanded the scale of budgetary expenditures and supported a large number of public works projects through borrowing. In the absence of necessary supervision, the issuance of local government bonds to build public works will become a means for local government officials to obtain political rents and economic rents, and is an opportunistic behavior applicable to all local officials.

\section{The start-up of the local government bond issuance management system}

In 1994, China carried out the tax-sharing system reform. This Chinese fiscal system reform realized a fundamental change from administrative decentralization to economic decentralization. However, it also caused the fact that the core of the authority to shift downward and the focus of the financial power moved upward. The local governments undertook more public administration affairs, which resulted in greater financial pressure. At the same time, both academic and political circles began to discuss the issue of local government bonds, and then the outbreak of the international financial crisis ultimately promoted the issuance of local government bonds.

In order to provide financial support for local economic development during the financial crisis, the Chinese government has publicly issued local government bonds since 2009. The initial issuance management system includes the "Notice on Preparatory Work of Issuing Local Government Bonds" in 2009, the "Ministry of Finance's Act of Issuing Local Government Bond Issuance Measures" in 2009, and the "Regulation Measures on the Administration of Local Government Bond Budgets in 2009". According to the specific provisions of the above notification, the initial distribution management system can be summarized into the following three aspects:

The first is the central administrative examination and approval system. In the second article of the "Regulation Measures on the Administration of Local Government Bond Budgets in 2009", the provinces, autonomous regions, municipalities directly under the Central Government and the municipal governments listed in the plan are designated as the main body of China local government public debt issuance and repayment. However, this Regulation Measures also emphasized that the local government's issuance of public debt must be approved by the State Council, and the specific issuance management of local government bonds, such as tendering, repayment of principal and interest, payment of fees should be submitted to the Ministry of Finance. According to the above institutional arrangements, the central government has completely dominated the issuance management of local government bonds through administrative approval.

The second is the central financial credit guarantee system. Article 10 of the "Regulation Measures on the Administration of Local Government Bond Budgets in 2009" stipulates that after the expiration of local government bonds, the Ministry of Finance shall arrange for repayment of principal and interest. Considering the rules of Chinese fiscal system, there are no rules and regulations on the bankruptcy of local governments. The central government has the responsibility of "Final Debtor" for local government debt. Therefore, on the issuance of repayment of local government bonds, the Central Ministry of Finance provided actual credit guarantees for public debt issued by local governments.

The third is the bidding system that relies on the national debt channel. At present, Chinese local government bonds are mainly issued through tendering and targeted underwriting. According to the "Regulations on Bidding and Evaluation of Local Government Bonds" promulgated each year, the tendering rules for Chinese local government bonds are not substantially different from the tendering 
rules for national debt. It can be argued that the issuance of Chinese local government bonds is basically dependent on the existing issuance channels of government bonds.

Through the basic description of the above three aspects, Figure 1 outlines the system of China local government bond issuance management system in the initial stage.

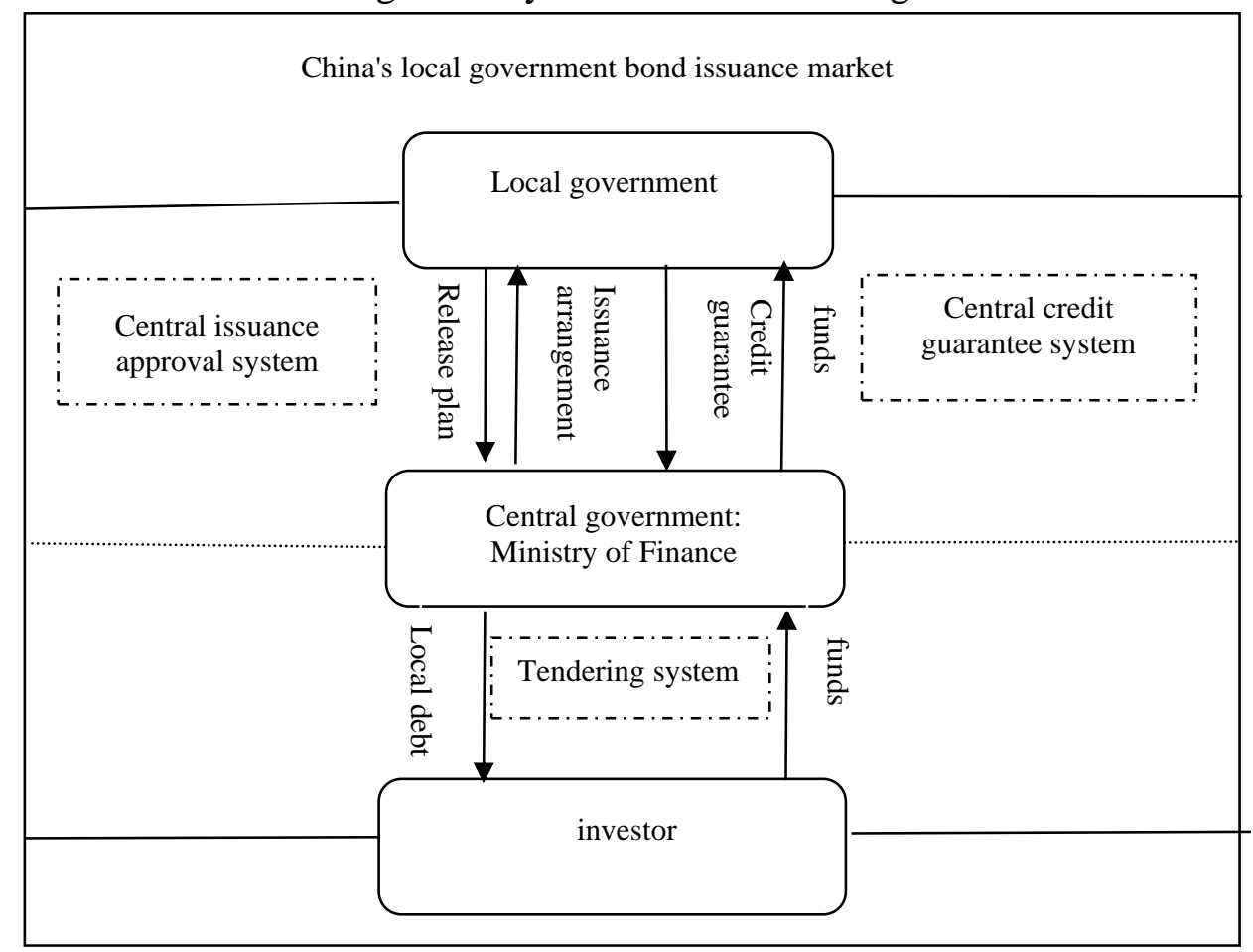

Fig.1 The newly created Chinese local government bond issuance management system

The initial local government bond issuance management system is a typical administrative control model. The system has two prominent market performances: First, the administrative control model ensures that local governments obtain a relatively stable supply of funds. By using the existing national debt issuance channels, supplemented by the central government's credit guarantees, the central government smoothly issued 200 billion bonds on behalf of local governments, and raised the necessary financial funds for local implementation of active fiscal policies. This shows the stable financing ability unique to the administrative control model during the financial market downturn. Second, the administrative control model has restricted the expansion and in-depth development of the local government bond market. The local government bonds issued by the Ministry of Finance rely on the original government bond issuance channels. The central government's credit guarantees have led to the stagnation of the information disclosure system and credit rating system of local government bonds, which has left most investors away from the secondary market of local government bonds. The secondary market for Chinese local government bonds with a sluggish trading and lack of sufficient liquidity has hindered the expansion of the primary market.

\section{Development of Local Government Bond Issuance Management System}

Since the initial issuance in 2009, Chinese local government bonds have been slowly developing, and the annual issuance scale has remained at a level of 100 billion yuan. However, the adoption of the new "Budget Law" in 2014 removed the institutional barriers that restricted local governments from issuing bonds. In September 2014, State issue No. 43 "State Council's Opinions on Strengthening Local Government Debt Management" clarified that the local government debt remediation will be based on the basic principles of "open aboveboard channels and blocking stealthy passages". As a result, the development of local government bond systems has entered the fast lane. The central government successively promulgated the "Measures for the Administration of Local Government General Debt Budgets" and the "Measures for Local Government Special Debt Budget Management", 
thus determining the new pattern of parallel development of two bond types, general bonds and special bonds. At the same time, in the "Opinions on Doing a Good Job in the Issuance of Local Government Bonds in 2018", it is required to improve the credit rating and information disclosure mechanism of local government bonds. It can be argued that the Chinese local government bond issuance management system has completed the following important developments:

The first is the decentralization of partial approval power. In 2011, the Central Ministry of Finance launched pilot projects for local governments to issue bonds in Shanghai, Zhejiang, Guangdong and Shenzhen. In 2014, it announced the granting of self-paying rights to 10 provinces and cities. The new budget law, which was implemented on January 1, 2015, gives local governments the right to issue government bonds to borrow debts. Local government bonds have thus entered a new phase of "spontaneous self-sufficiency".

Second, the product structure is diversified. Since 2015, local government bonds have been classified into general bonds and special bonds. General bonds are issued for non-profit public welfare projects, repaying principal and interest on general public budget income, and included in general public budget management. The issueable period is 1 year, 2 years, 3 years, 5 years, 7 years, 10 years. , 15 years and 20 years. Special bonds are mainly used for public welfare projects that generate certain income, and are repaid by local government funds or special income, and included in the fund budget. The bond varieties include special bonds for land reserve, special bonds for toll roads, special bonds for Shenzhen rail transit projects, and special bonds for shantytown renovation. The issuance period includes 1 year, 2 years, 3 years, 5 years, 7 years and 10 years. The above changes mean that the local government's capital needs and investors' investment needs are better matched.

The third is to establish an information disclosure system. In 2014, the Ministry of Finance issued the "Sponsored Measures for Spontaneous Self-Responsibility of Local Government Bonds in 2014", which required local government bonds to carry out credit ratings for the first time, and publicly disclosed the economic and financial status of debt issuers and debt data. At the end of December 2018, the Ministry of Finance issued the "Measures for the Disclosure of Local Government Debt Information". This Measures clarify the requirements for the disclosure of local government debt budget and final accounts, and the disclosure of local government bond information, and strengthen the supervision of information disclosure. Its content regulates the disclosure of local government bond information.

The fourth is to relax the restrictions of underwriters. The Chinese local government bonds in the initial period were completely dependent on the Dutch bidding method whith a single price, and the underwriters were also limited to the members of the government bond underwriting syndicate, which is very unfavorable for improving the efficiency of local government bond issuance and reducing the cost of issuance. With the advent of special bonds, the issuance of local government bonds has increased the number of targeted underwriting in addition to public offerings. The underwriter qualification also relaxes to legitimate financial institutions. 


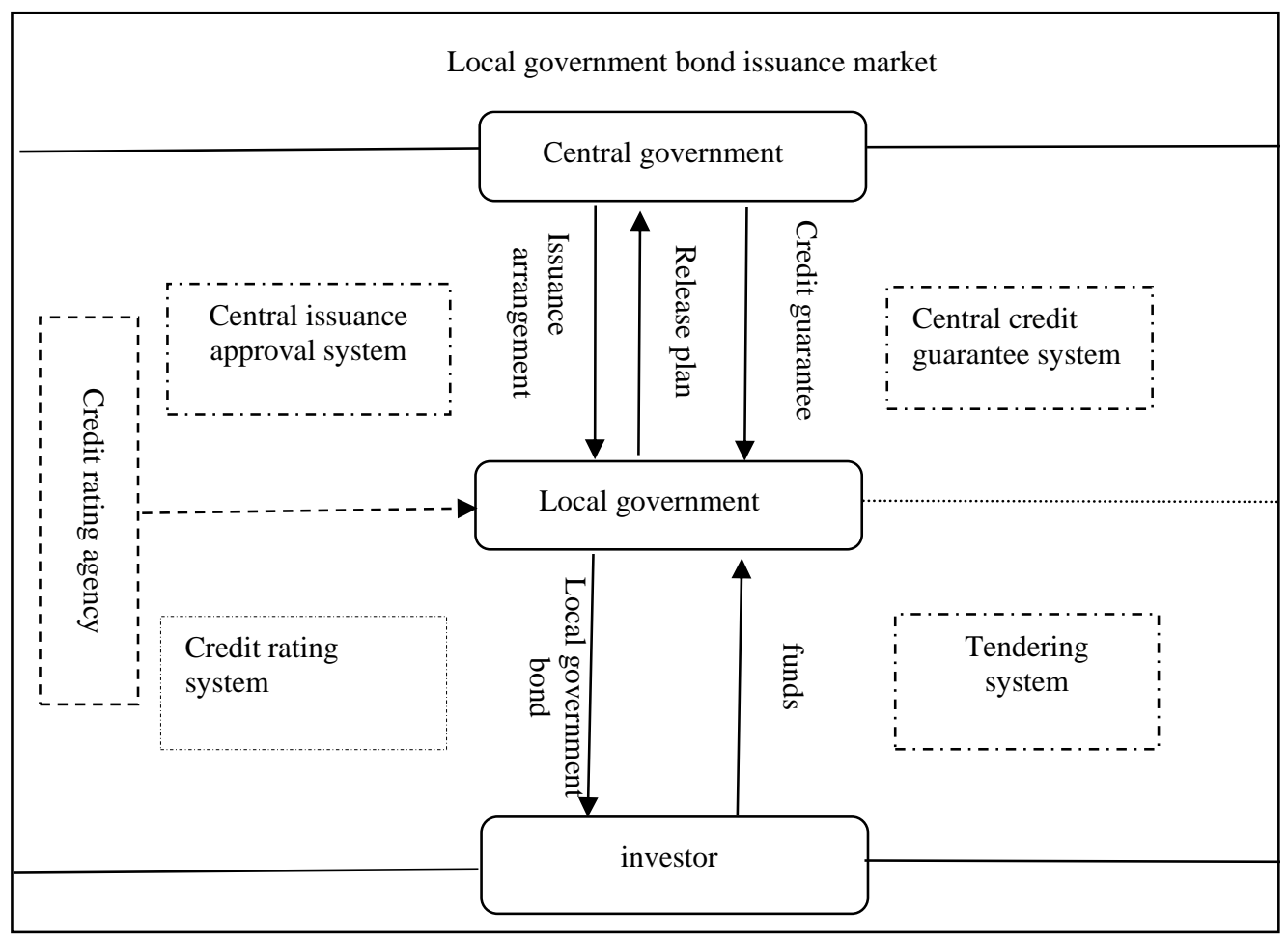

Fig. 2 Current China Local Government Bond Issuance Management System

The institutional structure of the developed Chinese local government bond issuance management system is shown in Figure 2. In response to the needs of local government and investor system requirements, the central government has conditionally placed the approval authority for some bonds, enriched the variety structure of bonds, and established a mandatory information disclosure system. A series of market-oriented institutional construction has promoted the in-depth development of the local government bond issuance market. After ten years of development, local government bonds have become Chinese largest kind of bond.

\section{Prospects for the Changes of Local Government Bond Issuance Management System}

The issuance and development of local government bonds does not mean that the central government despise the opportunistic behavior of local governments or the relaxation of local government debt supervision. However, after the promulgation of the new Budget Law, the central government gradually built a complete set of local debt management system. In the process of local government de-leveraging, local government bonds gradually replaced other local government financing platforms with their high transparency. However, since 2016, the continuous decline in the issuance of local government bonds has revealed that there is still room for improvement in Chinese local government bond issuance management system. Under the premise of effectively controlling the opportunistic behavior of local governments, Chinese local government bond issuance management system can be improved as follows: First, expand the scope of issuing subjects and grant the same issuing power to local governments at four levels to meet the financing needs of grass-roots local governments; Second, clarify the credit guarantee system, establish a special fund repayment fund and use methods, so that the credit rating of local government bonds can be relied upon; Thirdly, enrich the issuance method, gradually integrate with national bonds, expand the range of over-thecounter transactions by Banks, and fundamentally expand the breadth and depth of the local government bond issuance market. 


\section{Acknowledgment}

This research was financially supported by the 2019 Ningbo Social Science Planning Project "Study on the Moderate Issuance Scale of Local Government Special Bonds - Taking Ningbo City as an Example" (G19-ZX14).

\section{References}

[1] Vickrey, William.“ Counterspeculation, Auctions, and Competitive Sealed Tenders”, Journal of Finance, 16(March 1961) : 8 -37.

[2] Simon, David.“ Markups, Quantity Risk, and Bidding Strategies at Treasury Coupon Auctions”, Journal of Financial Economics, 35 (1): 43 -62.

[3] Back, Kerry and Jaime F. Zender." Auctions of Divisible Goods: On the Rationale for the Treasury Experiment”, The Review of Financial Studies, 6(4X 1993): 733-64.

[4] Chari, V.V. and Robert J.Weber.“ How the U.S.Treasury Should Auction Its Debt”, Federal Reserve Bank of Minneapolis Quarterly Review, Fall 1992:3 -12.

[5] Simonsen William \& Larry Hill (1998). "Municipal bond issuance: is there evidence of a principal-agent problem?”, Public Budgeting and Finance(4): 71- 100.

[6] Song Li. American municipal bonds and their enlightenment to China [J]. Macroeconomic Management, 2004 (9): 51 - 52.

[7] Vijay Krisna. Auction Theory [M]. Beijing: China Renmin University Press, 2010.

[8] Huang Wen, Wang Yibao. A Brief Analysis of the Issuance Methods of China's National Debt[J]. Shanghai Finance, 2001(12): 36-37.

[9] Robert Zipf. Municipal Bond Operation [M]. Beijing: Tsinghua University Press, 1998.

[10]Zhu Na, Hu Zhenhua, Ma Lin. A Comparative Study of US Municipal Bonds and China's Local Government Special Bonds[J]. Economic Geography, 2018(8): 29-36.

[11]Jiang Weizhuang, Wang Qian. Comparative Study on Local Bond Issuance Management[J]. Journal of Central University of Finance and Economics, 2009(10): 60-65.

[12]Deng Xiaolan, Xie Ping, Zhao Zhiyong. Research on local public debt risk from the perspective of new institutional economics [J]. Macroeconomic Research, 2010 (5): 62-66.

[13]Li Jingwei, Tang Xin. Thoughts on the Design of China's Local Government Bond Issuance System—-Based on International Experience and New Economic Sociology Perspective[J]. Social Scientist, 2014(6): 50 - 54.

[14] Yan Yan. The impact of the new extension of the new economic normal on the solvency of local governments and countermeasures [J]. Journal of Liaoning University: Philosophy and Social Sciences, 2017 (5): 51 -58. 